\title{
Penile Myiasis as a Differential Diagnosis for Genital Ulcer: A Case Report
}

\author{
Mauro R.L. Passos, Dennis C. Ferreira, Wilma N.C. Arze, José Carlos S. Silva, \\ Felipe D.L. Passos, and José Alexandre R. Curvelo \\ Department of Microbiology, Fluminense Federal University (UFF); Niterói, RJ, Brazil
}

\begin{abstract}
The genital localized myiasis is a rare zooparasitic dermatosis. This case reported to a penile myiasis by Dermatobia hominis larvae in a 62 year-old man, who is a retired military official from São Gonçalo city, Rio de Janeiro state, Brazil. This patient was guided to the sexually transmitted diseases (STD) clinic from Universidade Federal Fluminense (UFF) by professionals from a urology outpatient clinic of a public hospital from Rio de Janeiro state. The exam showed a $2 \mathrm{~cm}$ diameter nodular lesion with a hyperemic area in the glands penis that had arisen 20 days before the exam. It evolved in a favorable way after larvae removal, through previous local anesthesia and slight pressure in lesion's base with the extraction of the larvae. Penile myiasis is not a very frequent situation, although it must be considered as an option in differential diagnosis of genital infectious diseases, even among people of low economical level, as in the case presented.

Key-Words: Myiasis, infections, penile, genital, dermatosis.
\end{abstract}

The term myiasis etymologically means: myie (fly); asis (disease). This disease is common in rural areas from tropical countries and is caused by dipterous larvae, which live in host's dead or living tissues [1].

The parasitic biontophage larvae of the healthy tissue cause the furunculoid myiasis, and the flies from the species Dermatobia hominis, Cochliomyia hominivorax and Oestrus ovis are the major responsible for this situation [2]. This disease is caused by dipterous larvae, which naturally develop over or inside vertebrates, feeding themselves with living tissues [3].

It is also possible to occur another type of myiasis, produced by the invasion of larvae which posses affinity for tissues under necrosis (necrobiontophage). This kind of disease is more frequently caused by flies from the genus Sarcophaga, Lucilia and Callitroga [4].

About larvae's morphology, they are typically segmented, cylindrical, white or gray, having variable sizes [4].

This disease affects more frequently uncovered areas of the body, where the eggs deposition becomes easier. Besides, myiasis is more common in rural areas and can be established in patients with precarious hygienic practices, psychiatric disturbances, diabetics, immunodeficiency and in patients of low economic level [2,4].

Initially, occurs the deposition of eggs accomplished by the female of the species $D$. hominis in the thorax of an insect, which will maturate after six days.

This way, as soon as the insect lands in a human being, these eggs will be deposited in the skin or in the mucosa, where they hatch from the egg stimulated by heat. The larvae's size, in initial stage, is about $1.5 \mathrm{~mm}$ and in a few minutes it will penetrate the host's skin, getting positioned in such a way

Received on 27 January 2008; revised 5 April 2008.

Address for correspondence: Dr. Dennis de Carvalho Ferreira. Rua Riodades, 132. Zip code: 24130-240. Niterói, RJ, Brazil. Phone: 5521 2625-5084/9601-9841. E-mail: denniscf@gmail.com.

The Brazilian Journal of Infectious Diseases 2008;12(2):155-157. (C) 2008 by The Brazilian Journal of Infectious Diseases and Contexto Publishing. All rights reserved. that their respiratory caudal spiracle stays out of the host and its anterior spiracle stays inside the host to promote its feeding. Following its natural development, after ten weeks, the larvae would fall on the soil to become a pupa and finally become an adult fly $[5,6]$.

The place of occurrence of the lesions caused by the larvae can be cutaneous, subcutaneous or in natural cavities like nose, ear, mouth, anus and genitals [3].

The objective of this report was to present a case of penile myiasis caused by larvae of the fly Dermatobia hominis, which enter in the differential diagnosis of genital ulcer.

\section{Case Report}

A 62 year-old, white, heterosexual male patient, who is a retired military official, who lives in Colubandê - São Gonçalo - Rio de Janeiro state (RJ) - Brazil, but having spent most part of your life in a small farm in Itaboraí city - RJ (metropolitan area), where he used to wear shorts and no underwear, and used to take care of several animals. He was guided by the General Police Hospital - Niterói (RJ) to the sexually transmitted diseases (STD) clinic (UFF - RJ) to treat the genital wound.

During the visit to the doctor he described that before presenting the lesion of 20 days of evolution, with nodular start and hyperemia in the gland penis, he was examined by an urologist and was medicated with a third generation quinolone for a seven-day period, with no improvement, evolving one week later with the appearance of a serohemorrhagic secretion and stitch in the region.

He self-administrated peroxide of hydrogen and a polyvalent dermatological cream (corticoid, antibiotic, antifungal), because he thought it was berne, that had infected his head sometime ago.

Examination of his genitalia demonstrated a nodular lesion, with a $2 \mathrm{~cm}$ diameter hyperemic area, with ulceration and a 3 mm diameter orifice from which serohemorrhagic material could be expressed (Figure 1). Through the orifice, it was possible to observe a larva moving inside the lesion. There was no associated lymphadenopathy. After antisepsis with 
iodopovidone, the patient was given a local anaesthesia of $2 \%$ lidocaine around the lesion's orifice, taking care to do not reach the larvae. The orifice was opened with surgical scissors to make easier the larvae removal. Thereafter, a manual pressure on the glands penis resulted in larvae expelling through the opened cavity. After that, the cavity was cleaned with sterile $0.9 \%$ sodium chloride solution and iodopovidone. To prevent secondary infection, it was prescribed ciprofloxacin $500 \mathrm{mg}$ one tablet at each 12 hours for three days and the patient received anti-tetanus immunization. The material removed (the larvae) was sent to be identified.

\section{Discussion}

Between the several alterations that may affect the male and the female genital tract, there are those which are characterized as sexually transmitted diseases (STD) and other dermatosis. The penile myiasis may be confounded in its diagnosis with genital inflammatory nodular lesion, specially when the patient lives in tropical countries, where this disease frequently occurs. There must also be done the differential diagnosis with furuncle, sweat gland abscess and impetigo [7]. The careful clinical history and the genital examination may lead to a correct diagnosis and to a successful treatment, without skin biopsies and/or the lesion excision, as happened in the present report (Figure 2).

The male genital infestation is rare, since the area is usually protected by clothes and is little accessible to the insects' contact [4]. Otherwise, in the present report the patient used to wear shorts and no underwear at most part of the time, taking care of several animals in a rural area. This fact collaborated to the exposure of his penis to the flies' oviposition.

The entomological study of the larva removed from the patient presented in this report classified the larva as Dermatobia hominis (Figure 3), which is widely distributed in both South and Central America [3]. These insects may transfer the eggs of Dermatobia hominis to the skin of humans or other animals as they land to feed themselves, collaborating to the larvae to come out from the eggs and their penetration in the healthy or wounded skin [8-10].

The treatment is mechanical and is done by larvae capture [4]. However, some experiment s were done to permit the larvae to come out by the use of suffocating topical medicines, such as powder iodoform, potassium permanganate 1:4000 and chloroform [5]. Systemic medicines, with intravenous, intramuscular and subcutaneous paths can also be used [4,11], this way, the use of ivermectin by oral administration can be suggested [3]. However, we think that the treatment with larva removal and local cleaning is much more cost-effective.

Myiasis is usually treated by the occlusion of the opened fistula with vaseline ointment, nail polish or, as a traditional remedy, pig fat, which makes larval breathing impossible [7,12]. After that, local anesthesia is administrated, followed by compression of the sides of the nodule, and the use of surgical tweezers to larval removal and exhaustive cleaning of the
Figure 1. Gland penis showing the nodular lesion with ulceration.

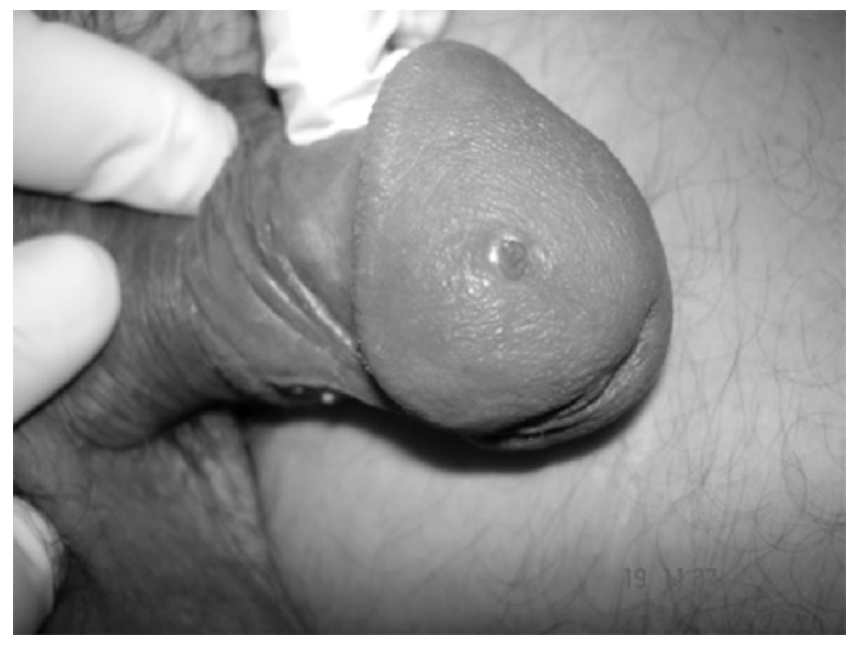

Figure 2. The aspect of the larva through the lesion orifice.

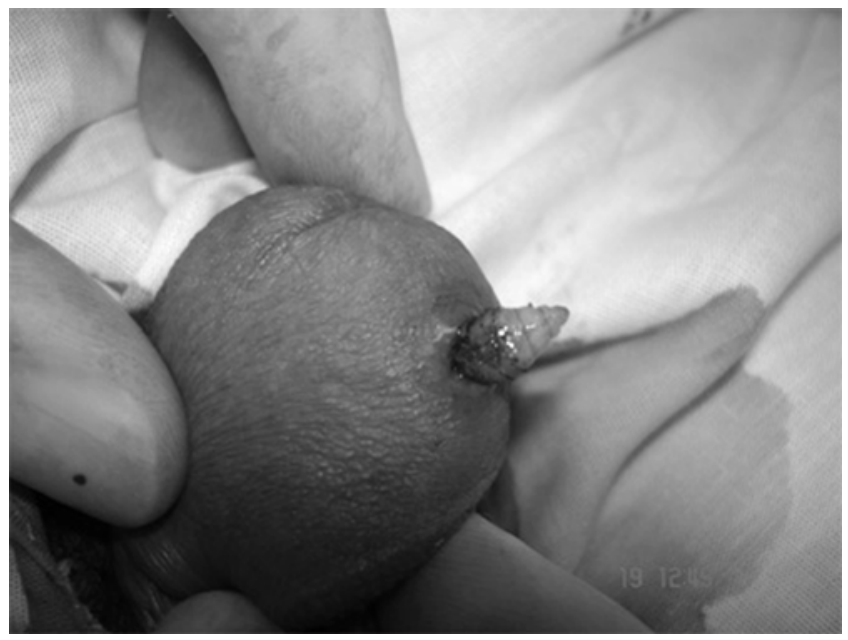

Figure 3. Larva of Dermatobia hominis following surgical removal from the penile lesion shown in Figure 1.

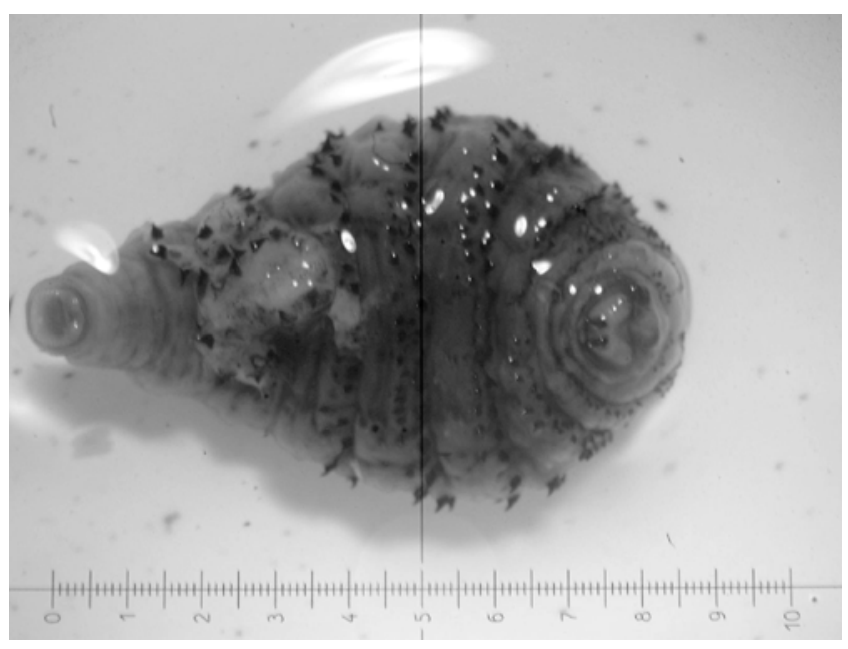


affected area. This procedure normally results in a successful removal. It is important to completely remove the larva, otherwise, the hole will not heal and may become a chronic infected wound. Afterwards, oral antibiotics should be administrated to prevent a secondary infection. All these procedures were accomplished in the present report, except the occlusion of the opened fistula with some obstructive agent [12].

As preventive measures we can emphasize the importance of the elucidation and orientations about myiasis to rural populations of low economical level, informing how to apply the basic principles of an adequate body hygiene, measures which improve the hygienic conditions of the habitations and the sanitary conditions [7].

\section{References}

1. Delir S., Handjani F., Emnad M., Aderhali S. Vulvar myiasis due to wohlfahrtio magnifica. Clin Exp Dermatol 1999;24:279-80.

2. Cilla G., Pico F., Peris A., et al. Human genital myiasis due to sarcophaga. Rev Clin Esp 1992;190:189-90.
3. Ribeiro F.A.Q., Pereira C.S.B., Alves A., Marcon M.A. Tratamento da míiase cavitária com ivermectina oral. Rev Bras Otorrinolaringol 2001;67:755-61.

4. Martinez C.A.R., Romani G., Prioli D.G., et al. Míiase Vulvar: Relato de caso. RBGO 2003;25:291-5.

5. Rey L. Dípteros braquíceros: moscas e motucas. In: Rey L, eds. Parasitologia, 3 edn. Rio de Janeiro: Guanabara Koogan, 2001:721-34.

6. Tsuda S., Nagaji J., Kurose K., et al. Furuncular cutaneous myiasis caused by Dermatobia hominis larvae following travel to Brazil. Int J Dermatol 1996;35:121-3.

7. Brasil, Ministério da saúde. Dermatologia na Atenção Básica. Secretária de políticas de saúde. 2nd edn. Brasília: Ministério da Saúde, 2002.

8. Hope F.W. On insects and their larvae occasionally found in the human body. Trans entomol soc London 1940;2:256-71.

9. Gomes P.A., Fukugava M.F.N., Cuce L.C. Míase vulvar. J. Bras Med 1996;70:106-8.

10. Cook G.C., Zumla A.L. Manson's tropical diseases. London: Sounders, 2002

11. Rodriguez G., Rashid M. Human scrotal myiasis (bot fly): a case of self diagnosis. J Urol 2001;16:1397-8.

12. Brewer T.F., Wilson M.R., Gonzalez E. Bacon therapy and furuncular myiasis. JAMA 1993;270:2087-8. 